\title{
Epidermolysis Bullosa Dystrophica, Autosomal Recessive
}

National Cancer Institute

\section{Source}

National Cancer Institute. Epidermolysis Bullosa Dystrophica, Autosomal Recessive. NCI

Thesaurus. Code C156446.

An autosomal recessive allelic variant of epidermolysis bullosa dystrophica caused by mutation(s) in the COL7A1 gene, encoding collagen alpha-1(VII) chain. 